\title{
Expansion in the Retail Sector-Market Entry Strategies in Consideration of Formal and Informal Institutions: A Tesco Case Study
}

\author{
Daniel Krummel \\ International Business and Management, Alliance Manchester Business School, Manchester, UK \\ Email: Daniel.krummel@yahoo.de
}

How to cite this paper: Krummel, D. (2022) Expansion in the Retail Sector-Market Entry Strategies in Consideration of Formal and Informal Institutions: A Tesco Case Study. Open Access Library Journal, 9: e8377. https://doi.org/10.4236/oalib.1108377

Received: January 16, 2022

Accepted: February 11, 2022

Published: February 14, 2022

Copyright $\odot 2022$ by author(s) and Open Access Library Inc.

This work is licensed under the Creative Commons Attribution International License (CC BY 4.0).

http://creativecommons.org/licenses/by/4.0/

\section{(c) (i) Open Access}

\begin{abstract}
Saturated domestic markets and increasing cost pressures, coupled with the expansion of the middle class across emerging markets, create a fertile environment for today's retailers to tap into new revenue potential abroad in countries like Indonesia. Commerce is an international business, giving retail giants, such as the British retailer Tesco, a wealth of experience in foreign markets. Yet, there are many modes of entry available to them, requiring detailed evaluation in the run-up to expansion. Each of those alternatives bears advantages and drawbacks. This work discusses joint venture, acquisition and greenfield investment as possible entry choices for Tesco when potentially entering the Indonesian market.
\end{abstract}

\section{Subject Areas}

International Management

\section{Keywords}

Formal and Informal Institutions, Indonesia, Market Entry Strategies, Tesco

\section{Introduction}

"Being a leading retailer today is not a guarantee (emphasis added) of value creation tomorrow. We need to ensure that we are tomorrow's leading retailer."

Sir Richard Broadbent (Chairman of Tesco) [1]

The expansion of the middle class in emerging markets allows for new sales potentials, which can be used to meet the increasing modernisation and competitive pressures faced by modern retailers [2] [3]. Simultaneously, a stable and growth-oriented global policy with increasing deregulation forms the optimal 
breeding ground for establishing international partnerships and opening up foreign markets [4]. As a matter of fact that retail companies on average operate 10 countries underpins the trend towards internationalisation [5] [6]. Hereof, enterprises have the choice between shared and full-control strategies. Yet, such a decision must be well conceived, since once a decision has been reached, reversal is virtually unfeasible, which consequently calls for pointed considerations [7] [8]. These deliberations are majorly driven by both the institutional differences and a firm's resources and capabilities [9] [10] [11]. Regarding the internationalisation of the British MNE Tesco, serving as a case study, it first ventured into South East Asia (SEA) in 1998 [12]. Ever since SEA has not lost its attractiveness as a strong economic region. The opposite is the case. In 2018, foreign direct investment (FDI) flows reached their all-time high of $\$ 149$ billion with Indonesia responsible for $\$ 22$ billion. Retail and wholesale trade were among the principal drivers [13].

The foremost endeavour of this essay is to investigate which market entry strategy would be most suitable for Tesco's potential market entry to Indonesia. To achieve this objective, the remainder of this paper is structured as follows: first, the institutional distance between home and host market is expounded. Second, three possible entry strategies are collated. Finally, a summarising conclusion is drawn.

\section{An Analysis of Institutional Distance}

Institutional distance is regarded as a major determinant of entry mode choice [14]. According to Kogut and Singh (1988) [15], companies tend to choose a less risky and less capital-intensive entry strategy when cultural distance is high. In contrast, it is argued that companies with a high cultural distance tend to adopt a high-risk strategy, which provides them with greater levels of control [16]. About previous entry mode research, its strong focus on manufacturing companies becomes evident [17]. Now, since retail companies act as an interface between the manufacturer and end consumer, direct customer contact demands culturally specific strategies. In other words, local adaptiveness is of paramount importance [18]. Consequently, the high application benefit of the institutional approach is thereby emphasised. Hence, the institution-based view (IBV) is most pertinent to analysing external factors [9]. In contrast, the RBV (internal) will be employed to reveal the company's capabilities in an internationalisation context [19] [20]. This combination of approaches provides a broad basis for the decision about Tesco's entry choice to Indonesia and thus seems to address the research question most clearly.

Both the Uppsala model and the Eclectic Paradigm are not being applied in this paper, as they were primarily developed for manufacturing companies [21] [22] [23]. Further, Dawson [24] expressly advises against a corresponding approach transfer to other sectors. Moreover, since the choice between greenfield and acquisition is rarely based on legal conditions, the legal distance will not be 
regarded in the following [25].

\subsection{Economic Distance}

Indonesia is considered to be the largest economy in SEA and forms the fourth largest population in the world [26]. Additionally, it is the only SEA country being part of the G-20 and also holds memberships in the ASEAN and the WTO [27].

As Table 1 illustrates, there are significant differences between the two countries in terms of economic strength. With a population density of around 77 Mio people, the British economy achieves a GDP of 45,740.75 USD, whereas Indonesia, with a population of nearly 268 million, generates a GDP of only $13,234.09$ USD. The inflation rate of $2.7 \%$ also indicates that households in the UK can use a higher proportion of their income for consumption than households in Indonesia, where the inflation rate is $3.8 \%$. Accordingly, the United Nations [28] classify Indonesia as an emerging and the UK as a developed economy.

Beyond that, the Global Competitiveness Report 2019 ranks Indonesia 50 and the UK 9 out of 141 countries worldwide. Here it becomes obvious that the two countries are far apart from each other in terms of global competitiveness [29].

Figure 1 displays the Economic Freedom Index 2021 with a World Average of 61.6 (Miller et al., 2019). Thailand (69.7) and Malaysia (74.4) were also added, as they belong to the same cultural cluster as Indonesia, which will receive further attention in Chapter 2.3 and 3.3. In 2016, Indonesia (2021: 66.9) almost caught up with Thailand (69.7) and also was significantly above the world average in 2019. Nevertheless, this indicator also underlines the clear economic distance to the UK with an overall score of 78.4 within the Economic Freedom Index of 2021 [31].

Besides institutional differences, it is also resource-based advantages having an immediate influence on the choice of market entry [7] [32]. Accordingly,

Table 1. Key facts about home and host country; own table, cited within.

\begin{tabular}{ccc}
\hline Key Figure & UK & Indonesia \\
\hline Population & $\begin{array}{c}66,488,991 \\
\text { (worldbank.org, 2019b) }\end{array}$ & $\begin{array}{c}\text { (worldbank.org, 2019b) } \\
\text { (wo35 }\end{array}$ \\
\hline GDP PPP & $\begin{array}{c}45,740.75 \\
\text { (imf.org, 2018) }\end{array}$ & $\begin{array}{c}13,234.09 \\
\text { (imf.org, 2018) }\end{array}$ \\
\hline GDP Growth Rate & $1.2 \%$ & $5.1 \%$ \\
\hline Inflation Rate & (oecd.org, 2019b) & (oecd.org, 2019a) \\
\hline Exchange Rate per USD & 2.7\% & $3.8 \%$ \\
& (cia.gov, 2017b) & (cia.gov, 2017a) \\
\hline
\end{tabular}




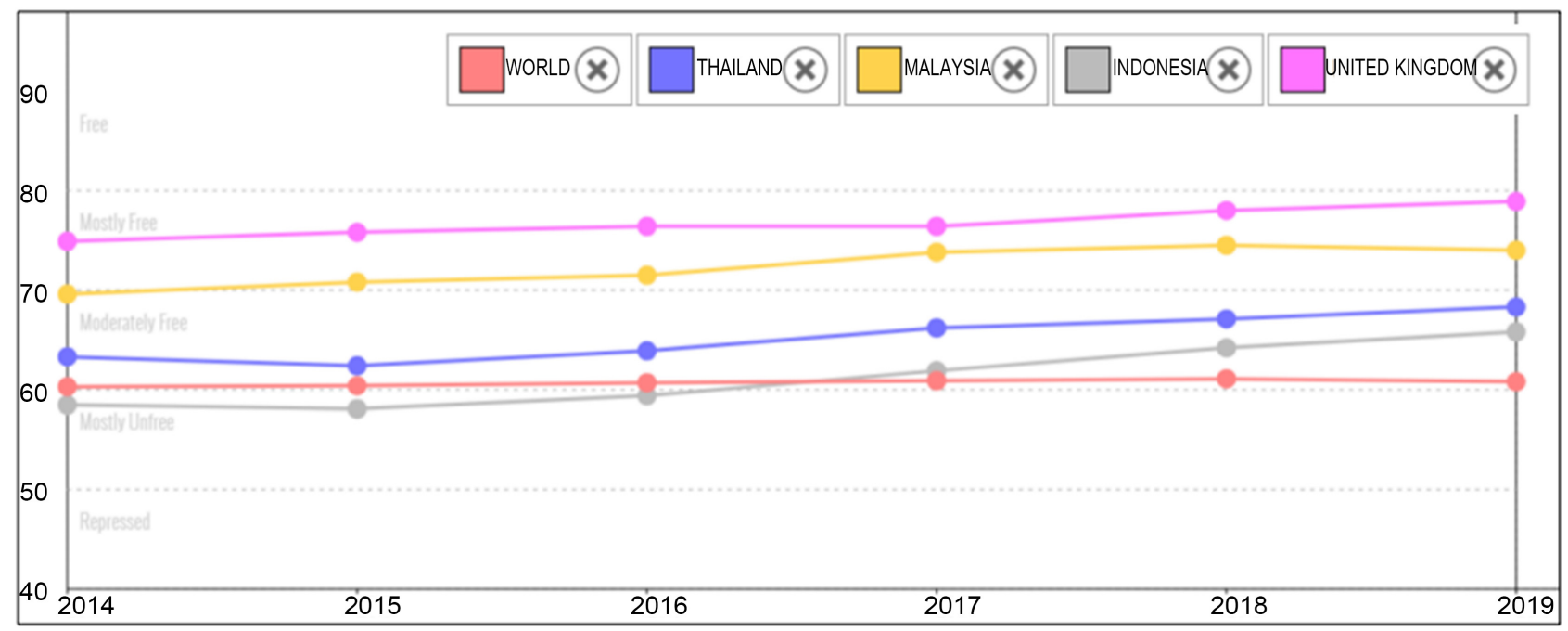

Figure 1. Index of economic freedom 2009-2021 [30].

Barney [33] perceives capabilities as internal resources that can yield competitive advantages to the company and which are used to align the corporate strategy. Mutinelli and Piscitello [34] pursue more specifically that experiences in the international competitive environment and thus accumulated knowledge are considered as a firm's capability. The RBV accordingly highlights international knowledge as an important capability of MNEs [35].

Further, Tesco already has a multitude of market experiences in Asia, such as Thailand and Malaysia [36]. About the RBV, it can be said that this experience expresses Tesco's capability and might be used as a valuable advantage for the successful implementation of a business concept under similar market conditions. Since Indonesia is part of the same cultural cluster as the aforementioned countries, valuable comparisons can be drawn [37].

Due to the limitation of this paper, chapters 2.2 and 2.3 will solely address significant factors, resulting in not every single dimension being discussed.

\subsection{Political Distance}

Political regulations constitute the formal institutional framework for companies [38]. Correspondingly, to assess the political distance between the UK and Indonesia this thesis employs the Worldwide Governance Indicators (WGI, see Appendix A).

Figure 2 illustrates that Indonesia and the UK differ significantly in all WGI indicators and thus the quality of governance, highlighting a general major political distance. Compared to the UK, the population in Indonesia has significantly less freedom of expression. Due to lower state effectiveness, Indonesia experiences poorer regulatory quality and thus reduced political stability. Less state-guaranteed security and increased crime rates are a logical consequence. The rule of law is, therefore, less pronounced in Indonesia than in the UK and, owing to a significantly higher rate of corruption, is additionally subject to judicial bending and less reliable. 


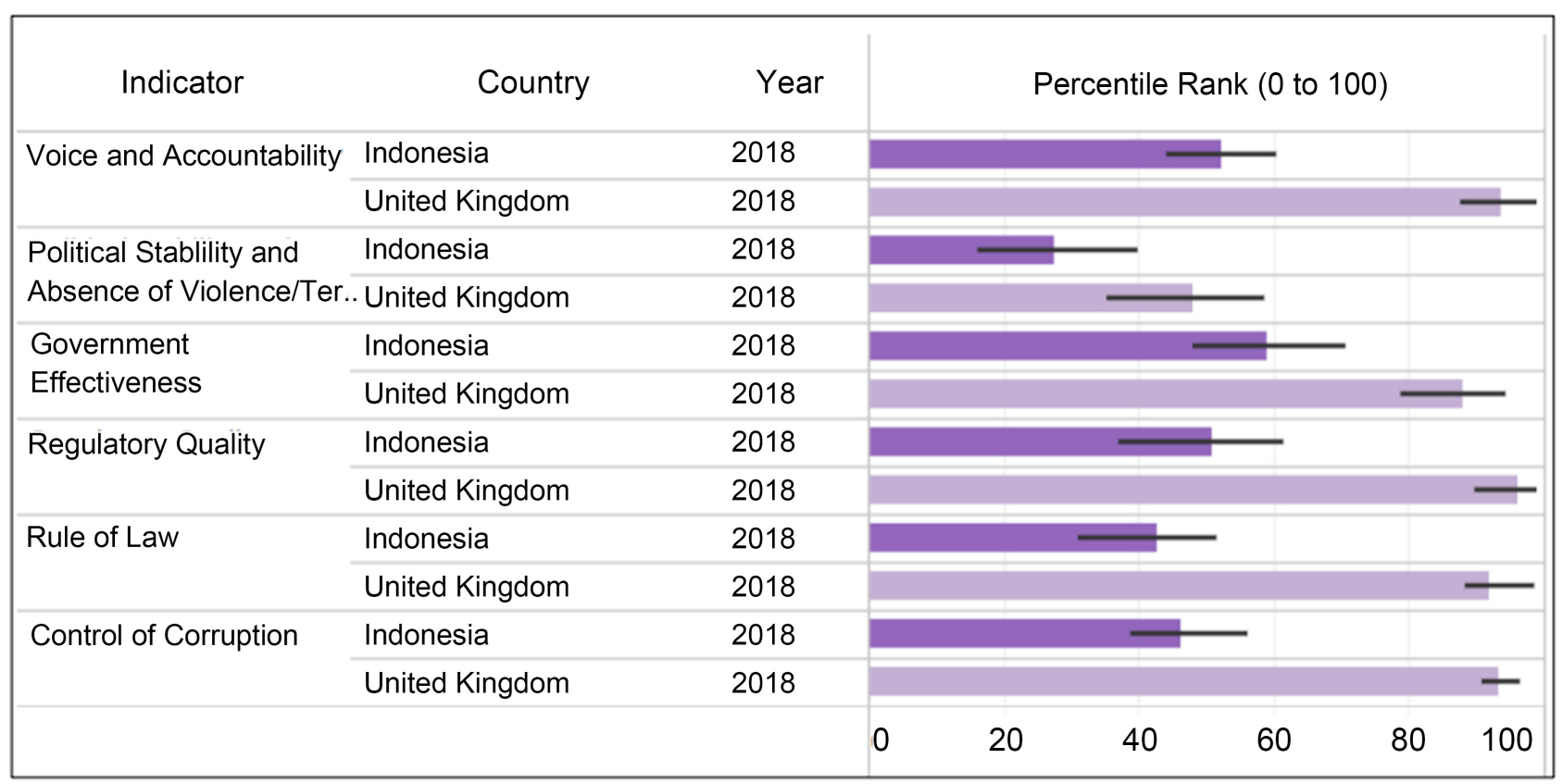

Figure 2. WGI related to the UK and Indonesia [39].

However, the low degree of Voice and Accountability in Indonesia (52\%, $22 \%$ ) could be an indication of limited advertising rights [39]. Due to the $87.2 \%$ Muslim portion of the population, additional restrictions of Tesco's advertising design might have to be considered [40].

Indonesia's Rule of Law indicator (42\%, 79\%) is pictured low [39]. It thus may be difficult for Tesco to obtain the validity of sales contracts or to legally enforce due invoices. The low level of Government Effectiveness and Regulatory Quality in Indonesia is another contributing severe factor.

Indonesia's poor ranking in the WGI Control of Corruption is underpinned by the Corruption Perceptions Index 2019 (Figure 3). Here, the difference in rank is 78 positions between Indonesia (89\%) and the UK (11\%) [41]. Subsequently, it can be deduced that a small elite largely determines market activity in Indonesia and that successful market entries also depend on the extent to which Tesco knows how to circumvent this situation [39].

\subsection{Cultural Distance}

This paper bases its cultural distance analysis on the GLOBE index (see Appendix B) of House et al. (2004). Despite the enormous influence of the Hofstede [42] [43] [44] approach, it has significant limitations which considerably restrict the utility of its application in this work. A crucial imperfection of using Hofstede is the deduction that since the results of his investigation are premised on mere cooperation with a single American company (IBM), the one-sided view is widely criticised. What makes this issue particularly difficult is its distortion of the Asian perspective [45]. Since the GLOBE study largely circumvents these limitations, it will be applied in the following [46] [47]. 


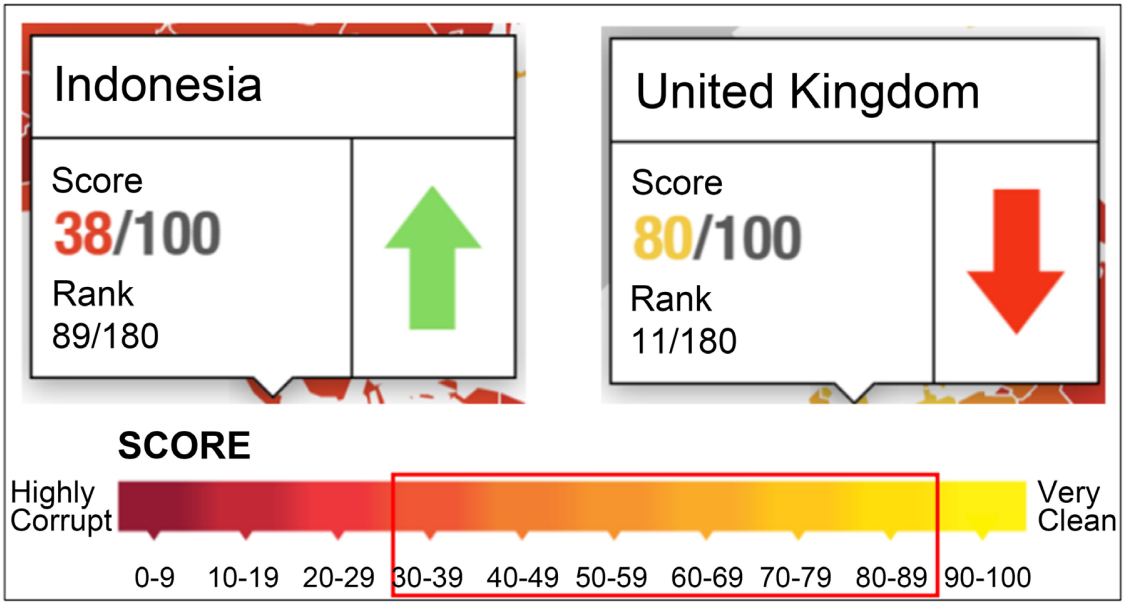

Figure 3. Corruption Perceptions Index 2019, adapted from Transparency International (2019).

This paper solely draws attention to the "practice" indices, as these are rested on actual values rather than just subjective preferences [48]. Besides a country-specific analysis, GLOBE also employs a classification of countries into cultural clusters. Accordingly, Indonesia, together with, inter alia, Thailand and Malaysia, forms the Southern Asia cluster. This classification is principally based on similar cultural values, norms and perceptions of corporate culture [49].

Figure 4 shows the legend for the following GLOBE graphs. The following charts show to what extent Indonesia and the UK perform on the GLOBE dimensions compared to the world average. The Country Value Score reflects the values that a culture ascribes to itself. The Country Practice Score, in contrast, reflects the actual reality and how these values are implemented within a country's culture. Besides, the exact GLOBE values of the individual indices are predicated on House et al. [37]

The Indonesian culture can be described as warm, open-hearted and tolerant [51]. Further, high levels of care and consideration for others contribute to Indonesia (4.69) achieving the world's highest GLOBE score in this category. In contrast, the English society (3.72) merely attaches relatively low importance to altruism and generosity, which can be extracted from Figure 5 [30]. The cultural difference could scarcely be greater. To deal with customers and business partners appropriately, special guidance is required to gain local acceptance.

Countries with a high score, such as Indonesia (5.68), in In-Group Collectiv$i s m$, are very family and group-work-oriented. In addition, a strict distinction is made between in-group and out-group, which subsequently determines their behaviour. The general pace of everyday life is rather moderate. By contrast, Figure 6 vivids that in England (4.08) behaviour is based on rational considerations, lower family orientation and a fast-paced everyday life [49]. As the English and Indonesian cultures also diverge here, Tesco needs to gain substantial knowledge about the proper way to create aligned working conditions.

As shown in Figure 7, the two societies also have different ideas about Gender 


\section{Country Value Score $\boldsymbol{\nabla}$ Country Practice Score I Average GLOBE Score \\ Range: Practices Range: Values}

Figure 4. Key to GLOBE Figures, adapted from [50].

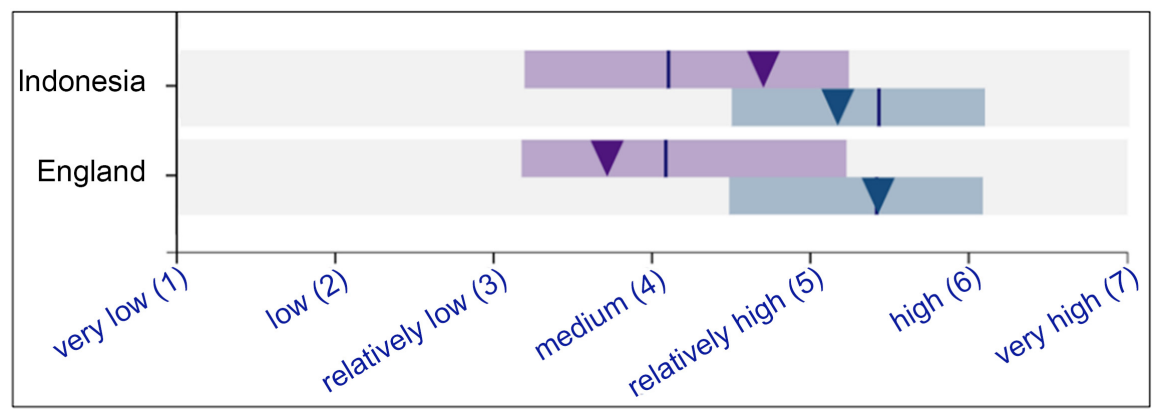

Figure 5. Humane orientation, adapted from [50].

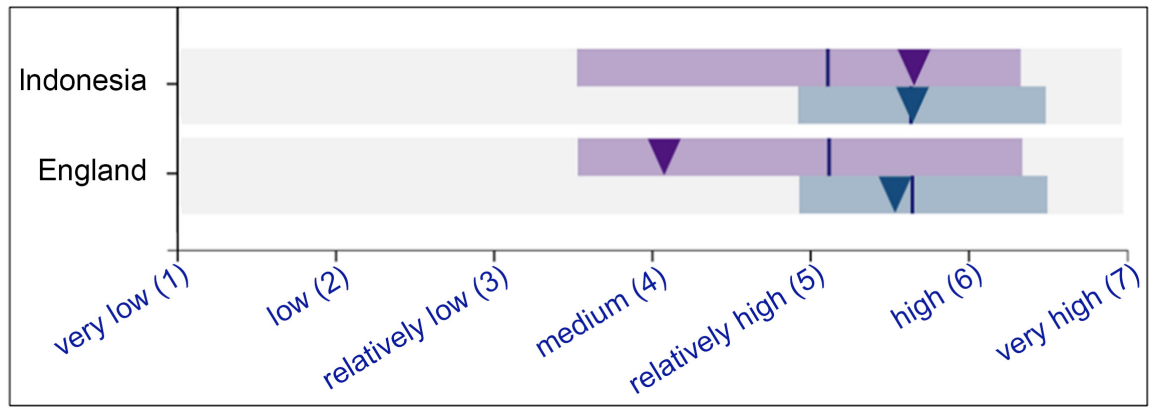

Figure 6. In-group collectivism, adapted from [50].

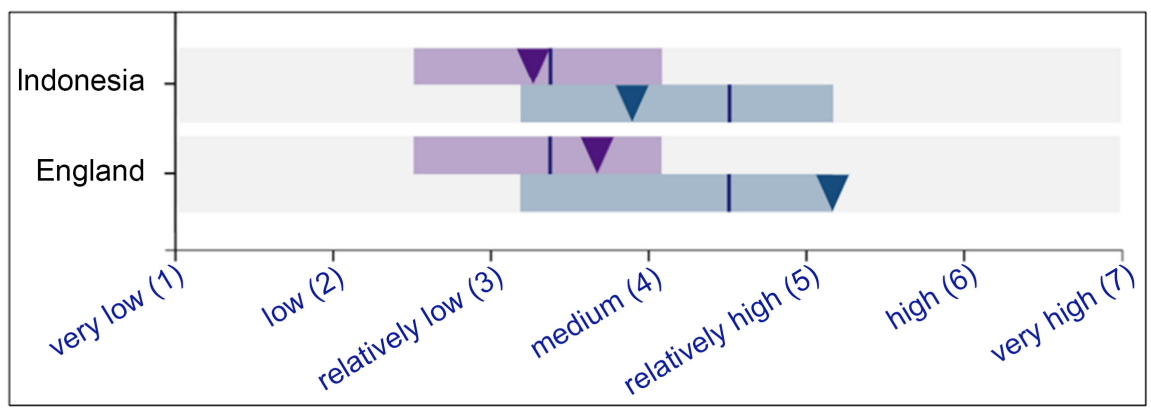

Figure 7. Gender egalitarianism, adapted from [50].

Egalitarianism. The score of 3.67 in England is also reflected in Tesco's gender-balanced corporate culture. Notably, the gender pay gap at Tesco of $8.9 \%$ is even below the already low UK national average of $17.9 \%$ in 2018 [36]. The fact that generally fewer women work in strategically responsible positions in Indonesian business (since 3.26) might also have an impact on the staffing of Tesco in Indonesia and its recruitment methods.

\section{Tesco Aiming for Indonesia}

This essay is limited to merely three equity entry modes, highlighted in Figure 8. 


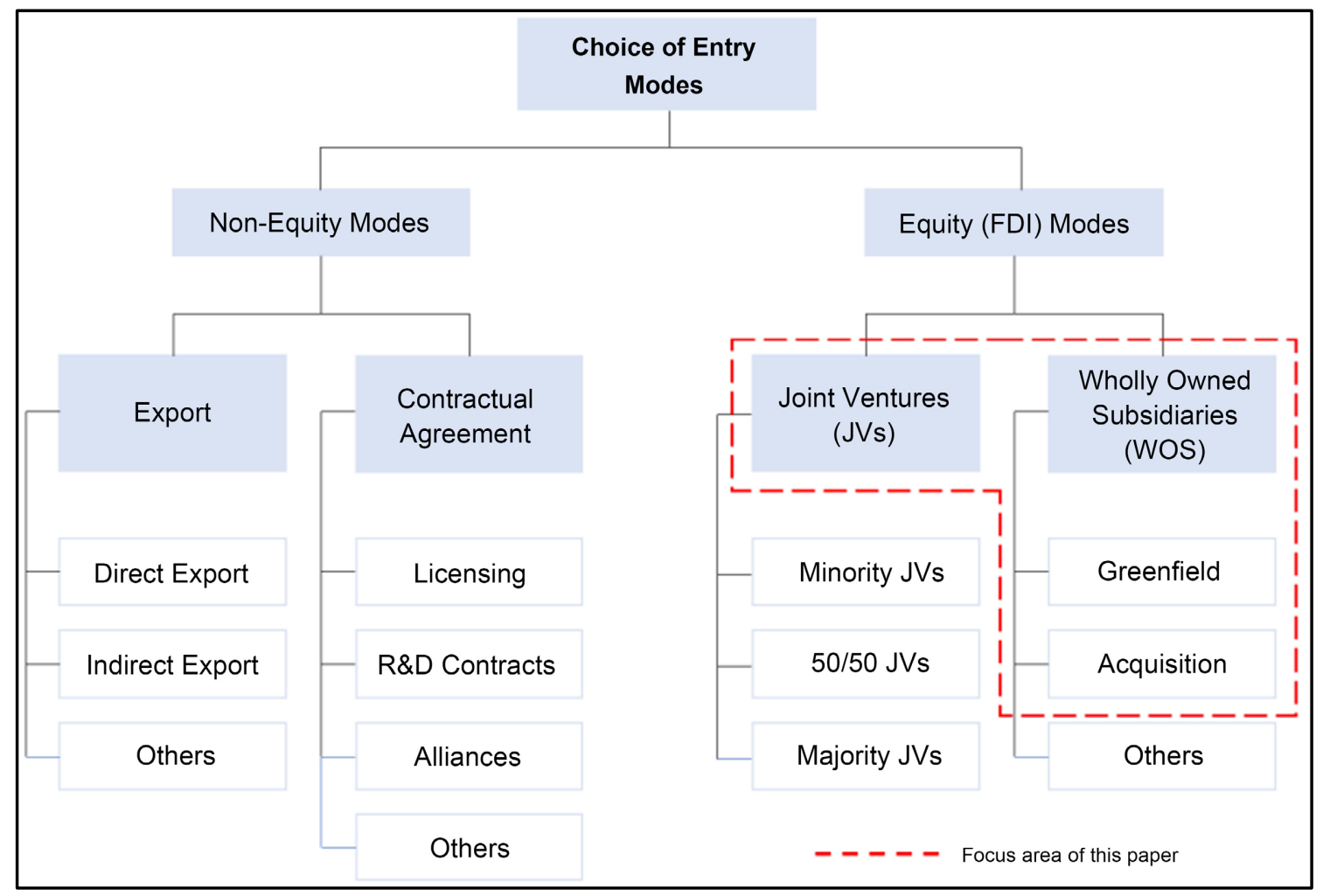

Figure 8. Market Entry Modes, own figure adapted from Pan and Tse [52].

Why the limited analysis of solely Joint Venture (JV), acquisition and greenfield? To evolve and to sell on a host market, retailers must first develop a distribution network with newly opened branches and initiate direct contact with the end consumer. Accordingly, it is not feasible for retailers to harness a classic export strategy as an initial market trial [18]. Similarly, referring to Tesco's formerly conducted entry strategies, illustrated in Chapter 3.3, it is mainly these three modes the retailer is familiar with and it is thus likely the choice would be one of those equity modes.

It is necessary to determine whether Tesco pursues a global or national responsiveness approach. Depending on this, it can be derived whether to use a shared or full control mode. In the case of the latter approach, a shared control mode is suitable, as it allows the local expertise of the partner to be exploited [53]. Furthermore, Tesco already holds 40 years of international experience [54]. By implication, internationalization, in general, is a key part of Tesco's overall strategy, reflected by 2038 stores and approximately 60,000 employees in Thailand and Malaysia alone [36]. The retailer's efforts to position itself in key regions and geographic proximity to markets already developed are evident (Ibid.). This positioning is intended to achieve economies of scale through overarching utilisable sourcing channels [55].

\subsection{Joint Venture}

In recent years, the realm of the international business environment has seen a 
significant increment in JVs [56] [57].

A major reason for foreign companies to enter certain economies through JVs is the restrictions on foreign equity participation in some developing countries [56]. Similarly, incomplete information about developing countries and associated transaction costs favour market entry via JVs [58] [59]. Furthermore, JVs can help firms gain legitimacy because partnering with a local firm can help to create structures and activities that conform with local norms and values [60]. $\mathrm{JV}$-modes offer access to knowledge about target market institutional contexts as well as better relations with local government representatives. Existing resourcebased advantages can thus be more fully exploited and provide opportunities to obtain and develop new firm-specific host market-related resources [61] [62]. This can create reciprocal synergies between the two companies and minimise financial risks and market uncertainties [63] [64]. Notwithstanding, Das and Teng [56] opine that JV relationships are inherently unstable and dissolve early. Accordingly, the average life of a JV is estimated at $5-7$ years [65]. Meschi and Riccio [66] confirm that cultural differences account for being the major reason for JV failure. Moreover, Yan and Zeng [67] claim the lack of trust and release of control between local and foreign partners to be particularly delicate. Besides, intercultural differences in business practices and a weak legal environment, typical for emerging markets, are some key risk factors leading to the dissolution of JV partnerships (Ibid.). In addition, Westman and Thorgren [68] state that unequal equity participation of the partners inevitably leads to partner conflicts.

\subsection{Acquisition}

Despite the high risk, acquisitions provide the acquiring company with high levels of control over strategy and daily business [69]. Acquisitions and JVs are preferred when the cultural distance between markets is high [25]. Further, food retailers tend to prefer entry modes with higher resource commitments [70].

Benefits such as the relatively rapid acquisition of, inter alia, established local brands and local intellectual capital appear to be tempting [71]. Increased bargaining power towards suppliers and thus lower purchasing costs and risk reduction through international diversification are also arguments in favour of acquisitions [72]. Likewise, gaining and securing knowledge within the company [73]. Nevertheless, acquisitions are complex processes that inevitably involve uncertainty. According to Huang and Kleiner [74], about three-quarters of acquisitions do not achieve the expected results. The insufficient degree of cultural similarity between companies is often cited as the reason for poor performance [75] [76]. Therefore, most acquisitions fail. A few may succeed, but on average acquisitions either destroy shareholder value or do not add any [72].

\subsection{Greenfield Investment}

Having no existing physical local organisation, Greenfields require the highest capital intensity among the three options, since everything has to be developed 
"from scratch" [77]. On the other hand, greenfield investments are characterised by maximum freedom of choice due to absolute control [78]. Yet, companies entering new markets entirely on their own particular face the liability of foreignness [79] [80] [81]. Padmanabhan and Cho [82] find that, where large differences between countries are given, multinational companies are more likely to set up new wholly-owned subsidiaries than to take over existing companies, since large country differences significantly increase the problems of implementing business practices. Whereas, $\mathrm{Xu}$ et al. [83] argue that as institutional distance rises, firms choose jointly controlled forms to reduce the risk of institutional conflict and loss of expertise owing to the knowledge of cultural values and norms as well as local market conditions. Even so, Kostova and Roth [84] expound, in line with Padmanabhan and Cho [82], that as institutional distance rises, firms choose greenfield investments because this facilitates the transfer of business practices. Buckley and Casson [85] agree by stating that high institutional distance goes hand in hand with high risk and companies accordingly choose to enter via full control modes.

Since traditional grocery retailers in Indonesia account for about $85 \%$ of sales, a strong preference for local products can be assumed [86]. Hence, a shared control mode is vitally needed to reduce foreign liability as well as discrimination to gain local acceptance, by developing proper local market concepts. Thus, local responsiveness is crucially necessary to meet customers' expectations. Because with high cultural distance, as it is given here, pursuing a global strategy is

Table 2. Tesco's internationalisation Strategies; own table, based on [54] [55].

\begin{tabular}{|c|c|c|c|c|}
\hline Year & Country/Area & Entry Mode & Cooperation Partner & Success or Failure \\
\hline 1979 & Ireland & JV & The Three Guys & Failure \\
\hline 1992 & France & $\mathrm{JV}$ & Catteau & Failure \\
\hline 1994 & Hungary & Acquisition & Global & Success \\
\hline 1995 & Poland & Acquisition & HIT & Success \\
\hline 1995 & $\begin{array}{c}\text { Czech Republic } \\
\text { and Slovakia }\end{array}$ & Acquisition & K-Mart & Success \\
\hline 1997 & Ireland & Acquisition & $\mathrm{ABF}$ & Success \\
\hline 1998 & Thailand & JV & Lotus & Success \\
\hline 1999 & South Korea & JV & Samsung & Failure \\
\hline 2000 & Taiwan, China & Greenfield & - & Failure \\
\hline 2001 & USA & Greenfield & - & Failure \\
\hline 2002 & Malaysia & JV & Sime Darby Behad & Success \\
\hline 2003 & Japan & Acquisition & C Two & Failure \\
\hline 2003 & Turkey & Acquisition & Kipa & Failure \\
\hline 2004 & China & Greenfield & - & Failure \\
\hline 2014 & India & JV & Tata Group & Success \\
\hline
\end{tabular}


extremely risky [87]. Beyond that, Padmanabhan and Cho [82] state that empirical knowledge related to particular entry modes through previous use and resulting routines facilitate the re-use of the same model. For instance, the strategic knowledge gained through JVs subserves the reduction of institutional distances [88]. According to the RBV, Tesco already has valuable international experience (see Table 2). This knowledge might be applied to the Indonesian market entry. Yet, within the Southern Asia cluster countries may differ in certain areas, so additional local knowledge would be advantageous. Previous success has also shown that JV is a proven means of success for Tesco's entry into SEA.

Having presented the rationale, the author thinks that a JV is most suitable for the Indonesian market entry, in contradiction to e.g. Mutinelli and Piscitello [34] stating the more pronounced the market knowledge, the more likely a full-control entry strategy.

\section{Conclusions}

The aim of this paper was the evaluation of the most suitable entry strategy for Tesco aiming at the Indonesian market.

It has been shown that both institutional distance and resource-based advantages have a considerable impact on a company's strategic choice. Accordingly, a significant distance between the UK and Indonesia in economic, political and cultural terms was illustrated. Nonetheless, regarding the conclusion of such distances, the sentiments of scholars differ. Some argue in favour of full-control modes to address high distances, others object, advising for shared-control entry. However, the prevailing view here is that a large distance leads to increased uncertainty, which might yet be reduced by local market insights and connections to important decision-makers within the host market. It hence stands to reason that the more Tesco accepts country-specific cultural differences and takes government policy into account in all its decisions, the greater the chances of success. In this connection, a knowledgeable local partner might facilitate this even more. Tesco already has empirical knowledge in Southern Asia and is therefore familiar with similar cultural conditions. Beyond that, previous entry modes of Tesco into SEA have been JVs, proven successful. Accordingly, the author holds that it is more than reasonable to choose the same entry mode for Indonesia, as experiences and organisational structures are already present.

As with any scientific work, this one too is certainly not void of optimization. To evaluate the realistic feasibility of the chosen market entry strategy, expert interviews, firstly with adequate representatives of Tesco and secondly with expansion experts, would certainly have provided an additional significant contribution to this work's overall quality and validity.

Future researchers might also want to evaluate a specific business case by comparing it to other companies in the retail sector, rather than limiting themselves to just one company. This can certainly lead to additional valuable con- 
clusions.

A more in-depth and broad literature review could examine expansion strategies over time to see whether the temporal epoch also exerts an influence on the strategy to be chosen.

Finally, in line with Sir Richard Broadbent: today's success is no guarantee for tomorrow's success. Notwithstanding, a precise analysis of a host market coupled with lessons learnt from previous enlargements can significantly increase the likelihood of future success.

\section{Conflicts of Interest}

The author declares no conflicts of interest.

\section{References}

[1] Tesco PLC (2014) Annual Report and Financial Statements 2014. https://www.tescoplc.com/media/754692/annual_report_14.pdf

[2] Cavusgil, S.T., Deligonul, S., Kardes, I. and Cavusgil, E. (2018) Middle-Class Consumers in Emerging Markets: Conceptualization, Propositions, and Implications for International Marketers. Journal of International Marketing, 26, 94-108. https://doi.org/10.1509/jim.16.0021

[3] Siegfried, P. (2015) Trendentwicklung und strategische Ausrichtung von KMUs. EUL-Verlag, Siegburg.

[4] Triki, D. and Mayrhofer, U. (2016) Do Initial Characteristics Influence IJV Longevity? Evidence from the Mediterranean Region. International Business Review, 25, 795-805. https://doi.org/10.1016/j.ibusrev.2015.10.002

[5] Siegfried, P. (2013) Fallstudien zum Internationalen Management/International Trade 14 Fallstudien. AVM Akademische Verlagsgemeinschaft, Munich.

[6] Deloitte (2019) Global Powers of Retailing 2019.

https://www2.deloitte.com/content/dam/Deloitte/global/Documents/Consumer-Bu siness/cons-global-powers-retailing-2019.pdf

[7] Brouthers, K.D. and Brouthers, L.E. (2003) Why Service and Manufacturing Entry Mode Choices Differ: The Influence of Transaction Cost Factors, Risk and Trust. Journal of Management Studies, 40, 1179-1204. https://doi.org/10.1111/1467-6486.00376

[8] Siegfried, P. (2017) Corporate Strategic Management in Practice. AVM Akademische Verlagsgemeinschaft, Munich.

[9] Huang, Y. and Sternquist, B. (2007) Retailers' Foreign Market Entry Decisions: An Institutional Perspective. International Business Review, 16, 613-629. https://doi.org/10.1016/j.ibusrev.2007.06.005

[10] Siegfried, P. (2015) Die Unternehmenserfolgsfaktoren und deren kausale Zusammenhänge. Zeitschrift Ideen- und Innovationsmanagement. Deutsches Institut für Betriebswirtschaft GmbH/Erich Schmidt Verlag, 131-137. https://doi.org/10.37307/j.2198-3151.2015.04.04

[11] Siegfried, P. (2012) Strategic Business Planning in Young Small and Medium Enterprises, Performance Measurement/Management. Publishing House of Wroclaw University of Economics, Vol. 250, S.75-S.84.

[12] Tesco PLC (1999) Annual Report and Financial Statements 1999. 
https://www.tescoplc.com/media/754682/annual_report_1999.pdf

[13] United Nations (2019) World Investment Report 2019.

https://unctad.org/en/PublicationsLibrary/wir2019_overview_en.pdf

[14] Berry, H., Guillén, M.F. and Zhou, N. (2010) An Institutional Approach to CrossNational Distance. Journal of International Business Studies, 41, 1460-1480. https://doi.org/10.1057/jibs.2010.28

[15] Kogut, B. and Singh, H. (1988) The Effect of National Culture on the Choice of Entry Mode. Journal of International Business Studies, 19, 411-432. https://doi.org/10.1057/palgrave.jibs.8490394

[16] Chen, H. and Hu, M.Y. (2002) An Analysis of Determinants of Entry Mode and Its Impact on Performance. International Business Review, 11, 193-210. https://doi.org/10.1016/S0969-5931(01)00055-5

[17] Siegfried, P. (2013) Studies Analyse on Strategic Corporate Planning in SMEs. Entrepreneurship Conference, University of Lisboa/PRT, S.618-S.632.

[18] Jonsson, A. and Elg, U. (2006) Knowledge and Knowledge Sharing in Retail Internationalization: IKEA's Entry into Russia. The International Review of Retail, Distribution and Consumer Research, 16, 239-256. https://doi.org/10.1080/09593960600572316

[19] Siegfried, P. and Zhang, J. (2021) Developing a Sustainable Concept for the Urban Last-Mile Delivery. Open Journal of Business and Management, 9, 268-287. https://doi.org/10.4236/ojbm.2021.91015

[20] Siegfried, P. (2015) Strategische Unternehmensplanung in jungen KMU-Problemfelder und Lösungsansätze. de Gruyter/Oldenbourg Verlag. https://doi.org/10.1515/9783110429022

[21] Dunning, J.H. (1977) Trade, Location of Economic Activity and the MNE: A Search for an Eclectic Approach. In: Ohlin, B., Hesselborn, P.O. and Wijkman, P.M., Eds., The International Allocation of Economic Activity, Palgrave Macmillan UK, London, 395-418. https://doi.org/10.1007/978-1-349-03196-2_38

[22] Dunning, J.H. (1980) Toward an Eclectic Theory of International Production: Some Empirical Tests. Journal of International Business Studies, 11, 9-31. https://doi.org/10.1057/palgrave.jibs.8490593

[23] Siegfried, P. (2014) International Management: Fallstudien zum Risiko-, Krisen-, Changemanagement and Internationalisierungsstrategien. AVM Akademische Verlagsgemeinschaft, Munich.

[24] Dawson, J.A. (1994) Internationalization of Retailing Operations. Journal of Marketing Management, 10, 267-282. https://doi.org/10.1080/0267257X.1994.9964274

[25] Bätz, K. and Siegfried, P. (2021) Complexity of Culture and Entrepreneurial Practice. International Entrepreneurship Review, 7, 61-70. https://doi.org/10.15678/IER.2021.0703.05

[26] worldbank.org (2019) The World Bank in Indonesia-Overview. https://www.worldbank.org/en/country/indonesia/overview

[27] europa.eu (2019) Indonesia-Trade-European Commission. https://ec.europa.eu/trade/policy/countries-and-regions/countries/indonesia/

[28] United Nations (2019) World Economic Situation and Prospects 2019. https://www.un.org/development/desa/dpad/wp-content/uploads/sites/45/WESP20 19_BOOK-web.pdf

[29] World Economic Forum (2019) The Global Competitiveness Report 2019. http://www3.weforum.org/docs/WEF_TheGlobalCompetitivenessReport2019.pdf 
[30] heritage.org (2019) 2019 Index of Economic Freedom. https://www.heritage.org/index/

[31] Miller, T., Kim, A.B. and Roberts, J.M. (2019) 2019 Index of Economic Freedom. The Heritage Foundation, Washington DC.

[32] Meyer, K.E., Estrin, S., Bhaumik, S.K. and Peng, M.W. (2009) Institutions, Resources, and Entry Strategies in Emerging Economies. Strategic Management Journal, 30, 61-80. https://doi.org/10.1002/smj.720

[33] Siegfried, P. (2021) Business Management Case Studies. BoD Book on Demand, Norderstedt.

[34] Mutinelli, M. and Piscitello, L. (1998) The Entry Mode Choice of MNEs: An Evolutionary Approach. Research Policy, 27, 491-506. https://doi.org/10.1016/S0048-7333(98)00063-8

[35] Newbert, S.L. (2007) Empirical Research on the Resource-Based View of the Firm: An Assessment and Suggestions for Future Research. Strategic Management Journal, 28, 121-146. https://doi.org/10.1002/smj.573

[36] Tesco PLC (2019) Annual Report and Financial Statements 2019. https://www.tescoplc.com/media/476423/tesco_ar_2019.pdf

[37] House, R.J., Hanges, P.J., Javidan, M., Dorfman, P.W. and Gupta, V. (2004) Culture, Leadership, and Organizations: The GLOBE Study of 62 Societies. Sage Publications, Thousand Oaks, CA.

[38] Siegfried, P. (2015) Business Cases Internationalisation Strategies in Global Player Companies: Volume 1. AVM Akademische Verlagsgemeinschaft, Munich.

[39] worldbank.org (2018) Worldwide Governance Indicators 2018. https://info.worldbank.org/governance/wgi/Home/Reports

[40] US and CIA (2018) The CIA World Factbook 2018-2019. Skyhorse Publishing, La Vergne.

[41] Transparency International (2019) Corruption Perceptions Index 2018. https://www.transparency.org/files/content/pages/2018_CPI_Executive_Summary.p df

[42] Siegfried, P. (2017) Intercultural Management in Practice. AVM Akademische Verlagsgemeinschaft, Munich.

[43] Hofstede, G. (1991) Cultures and Organizations: Software of the Mind. McGrawHill, London, New York.

[44] Hofstede, G. (2001) Culture's Consequences: Comparing Values, Behaviors, Institutions and Organizations across Nations. 2nd Edition, Sage Publications, Thousand Oaks, CA.

[45] Bockhaus Odenthal, E. and Siegfried, P. (2021) Agilität über Unternehmensgrenzen hinaus-Agility across Boundaries. Bulletin of Taras Shevchenko National University of Kyiv. Economics, 3, 14-24. https://doi.org/10.17721/1728-2667.2021/216-3/2

[46] Parboteeah, K.P., Bronson, J.W. and Cullen, J.B. (2005) Does National Culture Affect Willingness to Justify Ethically Suspect Behaviors? A Focus on the Globe National Culture Scheme. International Journal of Cross Cultural Management, 5, 123-138. https://doi.org/10.1177/1470595805054489

[47] Kirkman, B.L., Lowe, K.B. and Gibson, C.B. (2006) A Quarter Century of Culture's Consequences: A Review of Empirical Research Incorporating Hofstede's Cultural Values Framework. Journal of International Business Studies, 37, 285-320. https://doi.org/10.1057/palgrave.jibs.8400202

[48] Schwens, C., Eiche, J. and Kabst, R. (2011) The Moderating Impact of Informal In- 
stitutional Distance and Formal Institutional Risk on SME Entry Mode Choice. Journal of Management Studies, 48, 330-351. https://doi.org/10.1111/j.1467-6486.2010.00970.x

[49] Chhokar, J.S., Brodbeck, F.C. and House, R.J. (2007) Culture and Leadership across the World: The Globe Book of In-Depth Studies of 25 Societies. Lawrence Erlbaum Associates, Mahwah, NJ.

[50] globeproject.com (2016) GLOBE Project-Result Visualization. http://www.globeproject.com

[51] Mulder, N. (1994) The Ideology of Javanese-Indonesian Leadership. In: Antlöv, H. and Cederroth, S., Eds., Leadership on Java: Gentle Hints, Authoritarian Rule, Taylor and Francis, Hoboken, 57-72.

[52] Pan, Y. and Tse, D.K. (2000) The Hierarchical Model of Market Entry Modes. Journal of International Business Studies, 31, 535-554. https://doi.org/10.1057/palgrave.jibs.8490921

[53] Prahalad, C.K. and Doz, Y.L. (1987) The Multinational Mission: Balancing Local Demands and Global Vision. Free Press, New York; Collier Macmillan, London.

[54] tescoplc.com (2019) Reports Archive-Tesco PLC. https://www.tescoplc.com/investors/reports-results-and-presentations/reports-archi vel

[55] Palmer, M. (2005) Retail Multinational Learning: A Case Study of Tesco. International Journal of Retail \& Distribution Management, 33, 23-48. https://doi.org/10.1108/09590550510577110

[56] Das, T.K. and Teng, B.-S. (2000) Instabilities of Strategic Alliances: An Internal Tensions Perspective. Organization Science, 11, 77-101. https://doi.org/10.1287/orsc.11.1.77.12570

[57] Nippa, M. and Reuer, J.J. (2019) On the Future of International Joint Venture Research. Journal of International Business Studies, 50, 555-597. https://doi.org/10.1057/s41267-019-00212-0

[58] Beladi, H. and Chakrabarti, A. (2008) Foreign Equity Participation under Incomplete Information. Journal of Economic Behavior \& Organization, 67, 279-295. https://doi.org/10.1016/j.jebo.2007.07.003

[59] Seipp, V., Michel, A. and Siegfried, P. (2020) Review of International Supply Chain Risk within Banking Regulations in Asia, US and EU Including Proposals to Improve Cost Efficiency by Meeting Regulatory Compliance. Journal Financial Risk Management, 9, 229-251. https://doi.org/10.4236/jfrm.2020.93013

[60] Dacin, M.T., Oliver, C. and Roy, J.-P. (2007) The Legitimacy of Strategic Alliances: An Institutional Perspective. Strategic Management Journal, 28, 169-187. https://doi.org/10.1002/smj.577

[61] Siegfried, P. (2014) Knowledge Transfer in Service Research-Service Engineering in Startup Companies. EUL-Verlag, Siegburg.

[62] Luo, Y. (2002) Contract, Cooperation, and Performance in International Joint Ventures. Strategic Management Journal, 23, 903-919. https://doi.org/10.1002/smj.261

[63] Balakrishnan, S. and Koza, M.P. (1993) Information Asymmetry, Adverse Selection and Joint-Ventures. Journal of Economic Behavior \& Organization, 20, 99-117. https://doi.org/10.1016/0167-2681(93)90083-2

[64] Tower, A.P., Hewett, K. and Fenik, A.P. (2019) The Role of Cultural Distance across Quantiles of International Joint Venture Longevity. Journal of International Mar- 
keting, 27, 3-21. https://doi.org/10.1177/1069031X19874040

[65] Kabiraj, T. and Sengupta, S. (2018) A Theory of Joint Venture Instability under Inter-Partner Learning. Research in International Business and Finance, 46, 363-372. https://doi.org/10.1016/j.ribaf.2018.04.008

[66] Siegfried, P. (2017) Interkulturelles Management am Beispiel erfolgreicher Unternehmenskonzepte. AVM Akademische Verlagsgemeinschaft, Munich.

[67] Yan, A. and Zeng, M. (1999) International Joint Venture Instability: A Critique of Previous Research, a Reconceptualization, and Directions for Future Research. Journal of International Business Studies, 30, 397-414. https://doi.org/10.1057/palgrave.jibs.8490076

[68] Westman, C. and Thorgren, S. (2016) Partner Conflicts in International Joint Ventures: A Minority Owner Perspective. Journal of International Management, 22, 168-185. https://doi.org/10.1016/j.intman.2015.12.002

[69] Agarwal, S. and Ramaswami, S.N. (1992) Choice of Foreign Market Entry Mode: Impact of Ownership, Location and Internalization Factors. Journal of International Business Studies, 23, 1-27. https://doi.org/10.1057/palgrave.jibs.8490257

[70] Alexander, N., Quinn, B. and Cairns, P. (2005) International Retail Divestment Activity. International Journal of Retail \& Distribution Management, 33, 5-22. https://doi.org/10.1108/09590550510577101

[71] Anand, J. and Delios, A. (2002) Absolute and Relative Resources as Determinants of International Acquisitions. Strategic Management Journal, 23, 119-134. https://doi.org/10.1002/smj.215

[72] Siegfried, P. (2021) Strategic Management Business Cases and Management Concepts. BoD Book of Demand, Norderstedt.

[73] Peng, M.W. (2014) Global Strategic Management. 3rd Edition, South-Western, Cengage Learning, Mason, $\mathrm{OH}$.

[74] Huang, C.T.W. and Kleiner, B.H. (2004) New Developments Concerning Managing Mergers and Acquisitions. Management Research News, 27, 54-62.

https://doi.org/10.1108/01409170410784473

[75] Siegfried, P. (2013) The Service Engineering Concept for Business. Entrepreneurship Conference, University of Lisboa/PRT, S.173-S.187.

[76] Cartwright, S. and Cooper, C.L. (1996) Managing Mergers, Acquisitions, and Strategic Alliances: Integrating People and Cultures. 2nd Edition, Butterworth-Heinemann, Oxford, Boston. https://doi.org/10.1016/B978-0-7506-2341-4.50003-5

[77] Chen, S.-F.S. (2008) The Motives for International Acquisitions: Capability Procurements, Strategic Considerations, and the Role of Ownership Structures. Journal of International Business Studies, 39, 454-471. https://doi.org/10.1057/palgrave.jibs.8400357

[78] Contractor, F.J., Lahiri, S., Elango, B. and Kundu, S.K. (2014) Institutional, Cultural and Industry Related Determinants of Ownership Choices in Emerging Market FDI Acquisitions. International Business Review, 23, 931-941. https://doi.org/10.1016/j.ibusrev.2014.02.005

[79] Hymer, S. (1976) The International Operations of National Firms: A Study of Direct Foreign Investment. MIT Press, Cambridge, MA.

[80] Zaheer, S. and Mosakowski, E. (1997) The Dynamics of the Liability of Foreignness: A Global Study of Survival in Financial Services. Strategic Management Journal, 8, 439-463.

https://doi.org/10.1002/(SICI)1097-0266(199706)18:6<439::AID-SMJ884>3.0.CO;2-Y 
[81] Johanson, J. and Vahlne, J.-E. (2009) The Uppsala Internationalization Process Model Revisited: From Liability of Foreignness to Liability of Outsidership. Journal of International Business Studies, 40, 1411-1431. https://doi.org/10.1057/jibs.2009.24

[82] Padmanabhan, P. and Cho, K.R. (1995) Methodological Issues in International Business Studies: The Case of Foreign Establishment Mode Decisions by Multinational Firms. International Business Review, 4, 55-73. https://doi.org/10.1016/0969-5931(94)00031-G

[83] Xu, D., Pan, Y. and Beamish, P.W. (2004) The Effect of Regulative and Normative Distances on MNE Ownership and Expatriate Strategies. Management International Review, 44, 285-307.

[84] Kostova, T. and Roth, K. (2002) Adoption of an Organizational Practice by Subsidiaries of Multinational Corporations: Institutional and Relational Effects. Academy of Management Journal, 45, 215-233. https://doi.org/10.5465/3069293

[85] Buckley, P.J. and Casson, M. (1996) An Economic Model of International Joint Venture Strategy. Journal of International Business Studies, 27, 849-876.

https://doi.org/10.1057/palgrave.jibs.8490154

[86] Rangkuti, F.Y. (2018) Gain Report 2018-Indonesia Retail-Foods Retail. Global Agricultural Information Network.

https://apps.fas.usda.gov/newgainapi/api/report/downloadreportbyfilename?filena me=Retail\%20Foods_Jakarta_Indonesia_6-25-2018.pdf

[87] Kaufmann, D., Kraay, A. and Mastruzzi, M. (2011) The Worldwide Governance Indicators: Methodology and Analytical Issues. Hague Journal on the Rule of Law, 3, 220-246. https://doi.org/10.1017/S1876404511200046

[88] Li, J.J., Poppo, L. and Zhou, K.Z. (2010) Relational Mechanisms, Formal Contracts, and Local Knowledge Acquisition by International Subsidiaries. Strategic Management Journal, 31, 349-370. https://doi.org/10.1002/smj.813 


\section{Appendix}

\section{Appendix A: Definition of the World Governance Indicators}

1) Voice and accountability (VA) - capturing perceptions of the extent to which a country's citizens can participate in selecting their government, as well as freedom of expression, freedom of association, and free media.

2) Political stability and absence of violence/terrorism (PV)-capturing perceptions of the likelihood that the government will be destabilized or overthrown by unconstitutional or violent means, including politically-motivated violence and terrorism.

3) Government effectiveness (GE) - capturing perceptions of the quality of public services, the quality of the civil service and the degree of its independence from political pressures, the quality of policy formulation and implementation, and the credibility of the government's commitment to such policies.

4) Regulatory quality (RQ) - capturing perceptions of the ability of the government to formulate and implement sound policies and regulations that permit and promote private sector development.

5) Rule of law (RL) - capturing perceptions of the extent to which agents have confidence in and abide by the rules of society, and in particular the quality of contract enforcement, property rights, the police, and the courts, as well as the likelihood of crime and violence.

6) Control of corruption (CC) - capturing perceptions of the extent to which public power is exercised for private gain, including both petty and grand forms of corruption, as well as "capture" of the state by elites and private interests [88].

\section{Appendix B: Definition of the GLOBE Project Dimensions}

Power Distance: The degree to which members of an organization or society expect and agree that power should be stratified and concentrated at higher levels of an organization or government.

Uncertainty Avoidance: The extent to which a society, organization, or group relies on social norms, rules, and procedures to alleviate the unpredictability of future events.

Collectivism I, Institutional Collectivism: The degree to which organizational and societal institutional practices encourage and reward collective distribution of resources and collective action.

Collectivism II, In-Group Collectivism: The degree to which individuals express pride, loyalty, and cohesiveness in their organizations or families.

Gender Egalitarianism: The degree to which an organization or a society minimizes gender role differences while promoting gender equality.

Assertiveness: The degree to which individuals in organizations or societies are assertive, confrontational, and aggressive in social relationships.

Future Orientation: The degree to which individuals in organizations or societies engage in future-oriented behaviours such as planning, investing in the future, and delaying individual or collective gratification. 
Performance Orientation: The degree to which an organization or society encourages and rewards group members for performance improvement and excellence.

Humane Orientation is the degree to which individuals in organizations or societies encourage and reward individuals for being fair, altruistic, friendly, generous, caring, and kind to others [37]. 